\title{
In COVID-19 Suspicion Without Severe Manifestations, Chest CT Sensitivity is not Sufficient for Triage: A Single-centre Experience
}

\author{
Ciddi Belirtileri OImayan COVID-19 Şüphesinde, Göğüs BT Duyarlııı̆ı Triyaj Için Yeterli \\ Değildir: Tek Merkezli Bir Deneyim
}

 \\ Gümüş4, (1) Canan Demir5, (1) Abdulsamet Sandal5, (1) Mevlüt Karataş3 \\ ${ }^{1}$ Ankara Occupational and Environmental Diseases Hospital, Clinic of Radiology, Ankara, Turkey \\ ${ }^{2}$ Ankara Occupational and Environmental Diseases Hospital, Clinic of Infectious Diseases and Clinic Microbiology, Ankara, Turkey \\ ${ }^{3}$ Ankara Occupational and Environmental Diseases Hospital, Clinic of Chest Diseases, Ankara, Turkey \\ ${ }^{4}$ Ankara Occupational and Environmental Diseases Hospital, Clinic of Internal Medicine Ankara, Turkey \\ ${ }^{5}$ Ankara Occupational and Environmental Diseases Hospital, Clinic of Occupational Diseases, Ankara, Turkey
}

\section{Abstract}

Objectives: In Coronavirus diseases-2019 (COVID-19), chest computed tomography's (CT) benefits are controversial in the subgroup of asymptomatic and mild-to-moderate symptomatic individuals. Since most patients are in this subgroup, for triage, it is necessary to choose the diagnostic tool with the highest diagnostic performance and the least risk. We aimed to evaluate chest CT findings and the initial chest CT's sensitivity in individuals suspected of COVID-19 with no severe disease manifestations.

Materials and Methods: We conducted a retrospective study. Symptomatic individuals who had mild-to-moderate clinical manifestations and asymptomatic individuals who had close contact with confirmed COVID-19 positive patient were eligible. Presenting severe clinical manifestations was excluded. Reverse transcriptase-polymerase chain reaction (RT-PCR) and chest CT were performed on admission day. Consecutive nasopharyngeal and oropharyngeal swab sampling, tested by RT-PCR, were accepted as the reference standard for definitive diagnosis of COVID-19.

Results: COVID-19 was confirmed in 161 of 214 patients via consecutive RT-PCR test. In 67 of 161 patients, pneumonia was detected by the initial chest CT. Chest CT sensitivity was 41.6\% [95\% confidence interval (CI): $0.34-0.5$ ], while the sensitivity of the initial RT-PCR test was $90.96 \%$ (95\% $\mathrm{Cl}$ : 0.85-0.94); the area under the curve was significantly higher in the initial RT-PCR test $(p<0.05)$.

Conclusion: The chest CT is not sensitive enough to be used in the triage of individuals suspected with COVID-19 in this subgroup without the severe disease.

Key Words: COVID-19, SARS-CoV-2, Computed Tomography, Reverse Transcriptase Polymerase Chain Reaction

\section{$\ddot{0} z$}

Amaç: Koronavirüs hastalığı-2019'da (COVID-19), asemptomatik ve hafif-orta semptomatik bireylerden oluşan alt grupta göğüs bilgisayarlı tomografinin (BT) yararları tartışmalıdır. Çoğu hasta bu alt grupta olduğundan, triyaj için, en yüksek tanı performansına ve en az riske sahip tanı aracını seçmek gerekir. Ağır hastalık bulguları olmayan COVID-19 şüphesi olan bireylerde göğüs BT bulgularını ve ilk göğüs BT duyarlılığını değerlendirmeyi amaçladık.

Gereç ve Yöntem: Retrospektif bir çalışma yürüttük. Hafif-orta derecede klinik bulguları olan semptomatik bireyler ve COVID-19 pozitif hasta ile yakın temasta bulunan asemptomatik bireyler çalışmaya dahil edilmiştir. Ağır klinik bulguları olan bireyler dışlandı. Başvuru gününde ters

Address for Correspondence/Yazışma Adresi: Hakan Baş

Ankara Occupational and Environmental Diseases Hospital, Clinic of Radiology, Ankara, Turkey

Phone: +90 5386012814 E-mail: hakanbas7@outlook.com ORCID ID: orcid.org/0000-0001-8641-843X

Received/Geliş Tarihi: 12.05.2021 Accepted/Kabul Tarihi: 29.07.2021

๑Copyright 2021 Ankara University Faculty of Medicine

Journal of Ankara University Faculty of Medicine is published by Galenos Publishing House.

All content are under CC BY-NC-ND license. 


\section{Öz}

transkriptaz-polimeraz zincir reaksiyonu (RT-PCR) ve göğüs BT yapıldı. RT-PCR ile test edilen ardışık nazofarengeal ve orofarengeal sürüntüler, COVID-19'un kesin tanısı için referans standart olarak kabul edildi.

Bulgular: Ardışık RT-PCR testleri ile 214 bireyin 161'inde COVID-19 doğrulandı. Göğüs BT'de 161 hastanın 67'sinde pnömoni saptandı. Göğüs BT duyarlıı̆̆ \%41,6 [\%95 güven aralığı (GA): 0,34-0,5], iken ilk RT-PCR testinin duyarlılığı ise \%90,96 (\%95 GA: 0,85-0,94) bulundu. Eğrinin altındaki alan, ilk RT-PCR testinde daha yüksektir $(p<0,05)$.

Sonuç: Göğüs BT; COVID-19 şüphesi olan ve ağır hastalık bulguları olmayan alt grupta hasta triyajında kullanılacak kadar yeterli duyarlılıkta değildir. Anahtar Kelimeler: COVID-19, SARS-CoV-2, Bilgisayarlı Tomografi, Ters Transkriptaz Polimeraz Zincir Reaksiyonu

\section{Introduction}

The World Health Organization (WHO) declared Coronavirus diseases-2019 (COVID-19) as a pandemic on March 11, 2020. (1) Severe acute respiratory syndrome coronavirus-2 (SARS-CoV-2) is very contagious, transmitted by close contact, droplets, and aerosols (2). Common symptoms of COVID-19 are fever, cough, myalgia, and fatigue. Less common symptoms are sputum, hemoptysis, and diarrhoea. (3) The disease is known that can be asymptomatic in many individuals infected with the virus (4). Rapid and early diagnosis and isolation are crucial steps to deal with this contagious disease (5). Analysis of real-time reverse transcriptase-polymerase chain reaction test (RT-PCR) has been developed to diagnose COVID-19 (6). Many published studies highlighted the high rate of false-negative results for RT-PCR tests at the early stages of the outbreak $(7,8)$. Unavailability of RT-PCR and a high rate of false-negative RT-PCR results imply that most of the patients with COVID-19 may not have been detected. On the other hand, in regions with limitations, via characteristic computed tomography (CT) findings consistent with COVID-19 pneumonia, patients were diagnosed. Many published studies advocate that radiological examinations,

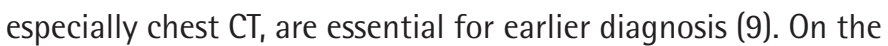
contrary, despite the confirmed cases, there may be COVID-19 negative on CT (5). This controversial situation raises concerns of unnecessary radiation exposure due to overuse of CT in the group without the severe disease, especially in asymptomatic patients. For the prevention of exposure to ionizing radiation, professionals published a guideline that advises using CT wisely (10). Damage at the cellular level and lifetime linear increase in cancer risk caused by ionizing radiation is observed with exposure even at low doses (11). Therefore, it is recommended to strictly adhere to ALARA principles (as low as reasonably achievable) and minimize unnecessary radiation exposure to protect COVID-19 patients from future cancer risks (12).

We aim to identify the sensitivity and findings of initial chest $\mathrm{CT}$ in the individuals with no severe disease suspected with COVID-19.

\section{Materials and Methods}

\section{Study design}

This study was a retrospective study, and approved by Clinical Research Ethics Committee of University of Health Sciences Turkey, Abdurrahman Yurtaslan Ankara Oncology Health Practice and Research Center (date: 24.06.2020, no: 2020-06/679). We included the participants referring to our institution between March 11, 2020, and June 1, 2020.

\section{Participants}

All enrolled individuals on admission day were evaluated for the severity of the disease according to WHO guidelines (13).

The inclusion criteria of the study are listed below:

a. Asymptomatic individuals with COVID-19 contact,

b. Symptomatic individuals who had mild-to-moderate clinical manifestations,

c. All participants should undergo initial RT-PCR and initial chest CT on admission day.

The exclusion criteria were as follows:

a. Being younger than 18 years old,

b. Presenting with severe clinical manifestations.

Total of 219 individuals was enrolled to study. Due to the lack of initial chest CT and severe disease, excluded patients numbers were 3 and 2, respectively. Consequently, 214 individuals who met the above criteria were enrolled.

\section{RT-PCR test, chest CT image techniques, and interpretation}

Consecutive nasopharyngeal and oropharyngeal swab sampling, tested by RT-PCR, were accepted as the reference standard for definitive diagnosis of COVID 19. When at least one of the sampling results was positive, the patients were diagnosed with COVID-19. Otherwise, when all the PCR test results of the samples were negative, COVID-19 was ruled out.

Initial RT-PCR tests were conducted on the admission day for all individuals. The initial RT-PCR test results were reviewed retrospectively regardless of the final diagnosis and were noted as positive or negative. 
All participants were scanned by chest $\mathrm{CT}$, at admission day for identifying pneumonia consistent with COVID-19. As the study was designed retrospectively, apart from routine chest CT protocol, a standard CT protocol was not followed. Images were acquired by one CT scanner [Somatom Emotion 6 Slice (DE), Siemens Healthcare, Germany]. After a deep breath, from the diaphragm to the thoracic inlet was scanned in caudocranial direction and the axial plane to prevent artefacts due to the diaphragm's movements. CT protocol with $130 \mathrm{kVp}, 100-200$ $\mathrm{mA}$, acquisition $6 \times 2.0 \mathrm{~mm}, 2.0 \mathrm{~mm}$ slice thickness, and sharp body kernel was applied, and no contrast agent was used.

A radiologist experienced for six years in thorax radiology was blinded to the final diagnosis, evaluated the images. As stated in the consensus, Interpretations of chest CT were classified as typical, intermediate, atypical, and negative (14). In terms of $\mathrm{CT}$ interpretations, typical and intermediate categories were evaluated as chest CT positive for COVID-19 pneumonia, while atypical and negative categories were considered negative.

\section{Statistical Analysis}

The statistical analysis was performed by using SPSS version 22.0. Continuous variables were expressed with mean \pm standard deviation, and categorical variables were reported as counts and percentages. Consecutive RT-PCR tests were accepted the reference standard for the definitive diagnosis of COVID-19. The sensitivity, specificity, positive predictive value (PPV), negative predictive value (NPV), and accuracy of the initial RT-PCR test and initial chest $\mathrm{CT}$ imaging were calculated by chi-square test. Also, the receiver operating characteristic (ROC) curves were used to compare the diagnostic performance of the initial chest CT with the initial RT-PCR test. Results for $p<0.05$ were considered statistically significant.

\section{Results}

Total of 214 patients, $161(161 / 214,75.2 \%)$ of them had at least one positive result of consecutive swab sampling and were diagnosed with COVID-19 positive, while 53 (53/214, 24.8\%) had negative results in all swab samplings and were verified to be COVID-19 negative.

Of 214 patients $36(36 / 214,16.8 \%)$ were asymptomatic while, $178(178 / 214,83.2 \%)$ were symptomatic. Asymptomatic 32 of $36(32 / 36,88.9 \%)$ patients were diagnosed as COVID-19, whereas $4(4 / 36,11.1 \%)$ were diagnosed as COVID-19 negative. Symptomatic 129 patients (129/178, 72.5\%) were diagnosed as positive, whilst $49(49 / 178,27.5 \%)$ patients were negative. The flowchart of the study is demonstrated in Figure 1. Demographic



Figure 1: Flowchart of the study

PCR: Polymerase chain reaction, CT: Computed tomography, COVID-19: Coronavirus disease-2019 
and clinical characteristics, symptoms, and comorbidities of 214 patients are summarized in Table 1.

Of the initial RT-PCR tests of 214 patients, 145 (145/214, $67.8 \%)$ were positive and $69(69 / 214,32.2 \%)$ were negative. The sensitivity, specificity, PPV, and NPV of the initial RT-PCR tests at the time of admission were 90.96\% [95\% confidence interval (Cl): $0.85-0.94$ ], 100\% (95\% Cl: $0.93-1), 100 \%$ and $76.81 \%$ (95\% Cl: 0.67-0.84), respectively. Accuracy rate was 93.04\% (95\% Cl: 0.88-0.95). In the initial Chest CT examination of 214 patients, $75(75 / 214,35 \%)$ patients had signs of pneumonia, while $139(139 / 214,65 \%)$ patients had no pneumonia. In patients diagnosed with COVID-19; 67 (67/161, 41.6\%) of 161 patients had signs of pneumonia in chest CT and no pneumonia was observed in $94(94 / 161,58.4 \%)$ patients. The sensitivity, specificity, PPV, and NPV of the initial chest CT examination at the time of admission are $41.6 \%(95 \% \mathrm{Cl}: 0.34-0.5), 84.9 \%$ (95\% Cl: $0.72-0.93), 89.3 \%$ (95\% Cl: $0.81-0.94)$, and $32.3 \%$ (95\% Cl: 0.28-0.36) respectively. Accuracy rate was 52.3\% (95\% $\mathrm{Cl}$ : 0.45-0.59). Comparison of the diagnostic performances are shown in Table 2.

Given the definitive diagnosis of COVID-19, the ROC curves, the area under the curve (AUC) comparing the initial RT-PCR test's diagnostic performance with the initial chest CT scan is shown in Figure 2. In this subgroup, which consisted of asymptomatic or symptomatic patients presenting with mild to moderate clinical findings, the initial RT-PCR test's diagnostic performance was better than the initial Chest CT of patients who were suspected with COVID-19. The AUC is significantly higher in the RT-PCR test. AUC was 0.95 (95\% Cl: 0.92-0.97) for RT-PCR test while it was 0.63 (95\% Cl: 0.55-0.71) for chest CT.

\begin{tabular}{|c|c|c|c|c|c|}
\hline & & All cases & CoVID-19 (-) & CoVID-19 (+) & p-values \\
\hline $\begin{array}{l}\text { Age }(y) \\
\text { (Mean } \pm \text { standard devia }\end{array}$ & & $33.9 \pm 10.7$ & $37.25 \pm 12.7$ & $32.78 \pm 9.79$ & $<0.05$ \\
\hline $\operatorname{Sex}(\%)$ & Female & $60(28 \%)$ & $17(28.3 \%)$ & $43(71.7 \%)$ & $>0.05$ \\
\hline \multirow[b]{4}{*}{ Comorbidities (\%) } & Hypertension (+) & $5(2.3 \%)$ & $1(20 \%)$ & $4(80 \%)$ & $>0.05$ \\
\hline & Diabetes (+) & $3(1.4 \%)$ & $1(33.3 \%)$ & $2(66.7 \%)$ & $>0.05$ \\
\hline & Coronary artery disease (+) & $1(0.5 \%)$ & $0(0 \%)$ & $1(100 \%)$ & $>0.05$ \\
\hline & $\begin{array}{l}\text { Chronic obstructive pulmonary disease } \\
(+)\end{array}$ & 0 & .. & .. & $>0.05$ \\
\hline \multirow{11}{*}{$\begin{array}{l}\text { Symptoms at present } \\
(\%)\end{array}$} & Asymptomatic & $36(16.8 \%)$ & $4(11.1 \%)$ & 32 (88.9\%) & \multirow{2}{*}{$<0.05$} \\
\hline & Symptomatic & $178(83.2 \%)$ & $49(27.5 \%)$ & $129(72.5 \%)$ & \\
\hline & Fever (+) & $65(30.4 \%)$ & $17(26.2 \%)$ & $48(73.8 \%)$ & $>0.05$ \\
\hline & Chilling (+) & $15(7 \%)$ & $4(26.7 \%)$ & $11(73.3 \%)$ & $>0.05$ \\
\hline & Cough (+) & $86(40.2 \%)$ & $19(22.1 \%)$ & $67(77.9 \%)$ & $>0.05$ \\
\hline & Sore throat (+) & $39(18.2 \%)$ & $13(33.3 \%)$ & $26(66.7 \%)$ & $>0.05$ \\
\hline & Myalgia (+) & $32(15 \%)$ & $6(18.8 \%)$ & $26(81.3 \%)$ & $>0.05$ \\
\hline & Fatigue (+) & $49(22.9 \%)$ & $11(22.4 \%)$ & $38(77.6 \%)$ & $>0.05$ \\
\hline & Headache (+) & $35(16.4 \%)$ & $3(8.6 \%)$ & $32(91.4 \%)$ & $<0.05$ \\
\hline & Chest pain (+) & $14(6.5 \%)$ & $8(57.1 \%)$ & $6(42.9 \%)$ & $>0.05$ \\
\hline & Abdominal pain (+) & $2(0.9 \%)$ & 0 & $2(100 \%)$ & $>0.05$ \\
\hline
\end{tabular}


The initial RT-PCR test results were positive in $145(145 / 161$ 90.1\%) of 161 patients diagnosed with COVID-19, while 16 (16/161, 9.9\%) patients yielded negative results. However, in those 16 patients, RT-PCR test positivity was demonstrated by consecutive swab sampling. The mean interval time between the initial negative and follow up positive RT-PCR results was $2.1 \pm 1.4$ days (mean \pm standard deviation). In these 16 patients, 8 were CT negative, while 8 were positive. Of the 8 patients whose first chest CTs were consistent with COVID-19, 7 of them

\begin{tabular}{|c|c|c|}
\hline & Initial RT-PCR test & Initial chest CT \\
\hline \multicolumn{3}{|l|}{ Results (n) } \\
\hline TP & 145 & 67 \\
\hline $\mathrm{TN}$ & 53 & 94 \\
\hline FP & 0 & 8 \\
\hline FN & 16 & 45 \\
\hline \multicolumn{3}{|c|}{ Diagnostic performance $(\%)(95 \% \mathrm{Cl})$} \\
\hline Sensitivity & $\begin{array}{l}90.96 \% \\
\text { (95\% Cl: } 0.85-0.94)\end{array}$ & $\begin{array}{l}41.61 \% \\
\text { (95\% Cl: } 0.34-0.5)\end{array}$ \\
\hline Specificity & $\begin{array}{l}100 \% \\
(95 \% \mathrm{Cl}: 0 \cdot 93-1)\end{array}$ & $\begin{array}{l}84.9 \% \\
(95 \% \mathrm{Cl}: 0.72-0.93)\end{array}$ \\
\hline PPV & $100 \%$ & $\begin{array}{l}89.3 \% \\
\text { (95\% Cl: } 0.81-0.94)\end{array}$ \\
\hline NPV & $\begin{array}{l}76.81 \% \\
\text { (95\% Cl: 0.67-0.84) }\end{array}$ & $\begin{array}{l}32.3 \% \\
(95 \% \mathrm{Cl}: 0.28-0.36)\end{array}$ \\
\hline Accuracy & $\begin{array}{l}93.04 \% \\
\text { (95\% Cl: 0.88-0.95) }\end{array}$ & $\begin{array}{l}52.3 \% \\
(95 \% \mathrm{Cl}: 0.45-0.59)\end{array}$ \\
\hline AUC & $\begin{array}{l}0.95 \\
\text { (95\% Cl: } 0.92-0.97)\end{array}$ & $\begin{array}{l}0.63 \\
(95 \% \mathrm{Cl}: 0.55-0.71)\end{array}$ \\
\hline
\end{tabular}

TP: True positive, TN: True negative FP: False positive, FN: False negative, PPV: Positive predictive value, NPV: Negative predictive value, AUC: Area under the curve, $n$ : Count, Cl: Confidence interval, CT: Computed tomography, RT-PCR: Reverse transcriptasepolymerase chain reaction

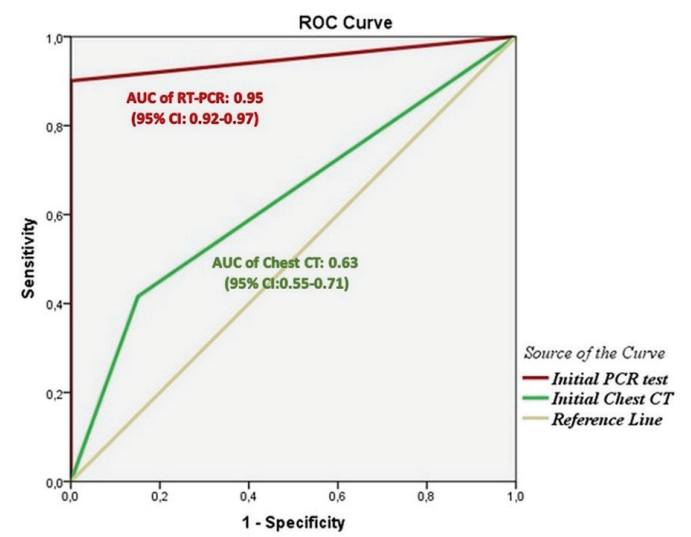

Figure 2: It displays ROC curve analysis of the diagnostic tools for COVID-19

Red and green texts in the graphic show the AUC values of each one ROC: Receiver operating characteristic, AUC: Area under the curve, $\mathrm{Cl}$ : Confidence interval, RT-PCR: Reverse transcriptase-polymerase chain reaction, CT: Computed tomography, COVID-19: Coronavirus disease-2019 were symptomatic, and 1 was negative, and these numbers were 6 and 2, respectively, in 8 patients that were CT negative. The definitive diagnosis of $8(8 / 75,10.6 \%)$ patients with CT negative were bacterial infections for 4 , pulmonary oedema for 3 , and asthmatic attack for 1 patient.

The CT findings of initial chest CT positive patients are noted in Table 3. Common CT findings predominantly involved the lower lobes with bilateral, peripheral, and peribroncovascular

\section{Table 3: The initial CT findings of the 67 patients with COVID-19 positive}

\begin{tabular}{|c|c|c|c|}
\hline & & n (67) & $\begin{array}{l}\text { Percent } \\
(\%)\end{array}$ \\
\hline \multirow{6}{*}{$\begin{array}{l}\text { Distribution } \\
\text { of findings }\end{array}$} & Bilateral & 42 & 62.7 \\
\hline & Unilateral & 23 & 34.3 \\
\hline & Peripheral & 61 & 91 \\
\hline & Central & 25 & 37.3 \\
\hline & Peribronchovascular & 39 & 58.2 \\
\hline & Perilobular & 23 & 34.3 \\
\hline \multirow{3}{*}{$\begin{array}{l}\text { Number of } \\
\text { lesions }\end{array}$} & Solitary & 17 & 25.4 \\
\hline & Multifocal & 46 & 68.7 \\
\hline & Diffuse & 1 & 1.5 \\
\hline \multirow{6}{*}{$\begin{array}{l}\text { Involved } \\
\text { Lobes }\end{array}$} & Right upper lobe & 31 & 46.3 \\
\hline & Left upper lobe & 26 & 38.8 \\
\hline & Middle lobe & 24 & 35.8 \\
\hline & Lingula & 17 & 25.4 \\
\hline & Right lower lobe & 47 & 70.1 \\
\hline & Left lower lobe & 41 & 61.2 \\
\hline \multirow{14}{*}{$\begin{array}{l}\text { Pulmonary } \\
\text { findings }\end{array}$} & Round & 56 & 83.6 \\
\hline & Ground glass opacity & 63 & 94 \\
\hline & Consolidation & 20 & 29.9 \\
\hline & Vascular enlargement & 46 & 68.7 \\
\hline & Crazy paving & 9 & 13.4 \\
\hline & Halo sign & 35 & 52.2 \\
\hline & Reversed halo sign & 4 & 6 \\
\hline & Air bronchogram & 19 & 28.4 \\
\hline & Nodules & 9 & 13.4 \\
\hline & Tree-in-but & 3 & 4.5 \\
\hline & Air trapping & 3 & 4.5 \\
\hline & Bronchiectasis & 1 & 1.5 \\
\hline & $\begin{array}{l}\text { Bronchial wall } \\
\text { thickening }\end{array}$ & 3 & 4.5 \\
\hline & Subpleural line & 9 & 13.4 \\
\hline \multirow{4}{*}{$\begin{array}{l}\text { Extra- } \\
\text { pulmonary } \\
\text { findings }\end{array}$} & Pleural effusion & 1 & 1.5 \\
\hline & Pleural thickening & 0 & .. \\
\hline & Lymphadenopathy & 0 & .. \\
\hline & Pericardial effusion & 0 & .. \\
\hline
\end{tabular}

CT: Computed tomography, COVID-19: Coronavirus disease-2019 
distribution, and there were multifocal, rounded, ground-glass opacities and vascular enlargements accompanying the lesions. Less common findings were air bronchogram, nodules, tree-inbud view, air trapping, bronchiectasis, bronchial wall thickening, pleural effusion, and subpleural lines (Figure 3-6). Pleural thickening and lymphadenopathy were not detected.

\section{Discussion}

COVID-19 may present with a wide range of clinical manifestations, from asymptomatic, mild-to-moderate disease to severe pneumonia and multiple organ dysfunction. Due to the nature of outbreaks, primarily severe cases are detected, while patients with asymptomatic and mild-to-moderate clinical findings are detected later by surveillance. Therefore, the delay
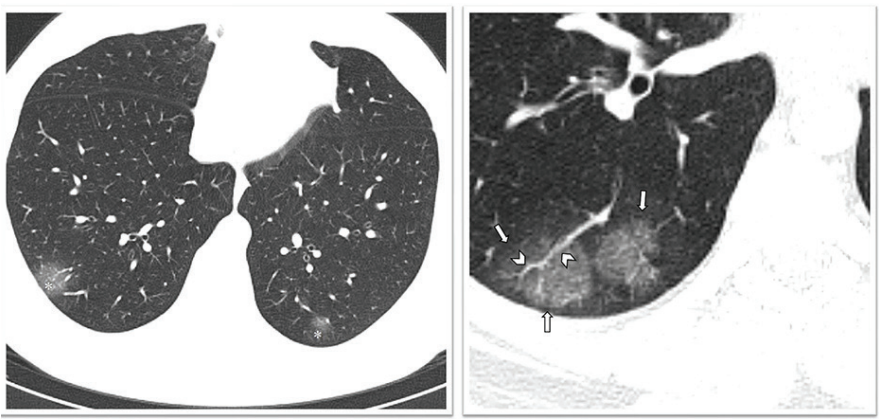

Figure 3: The CT findings of patients with COVID-19. On the left, round ground-glass opacities involving bilateral lower lobes and peripheral site of the lung are shown (asterisk). On the right, in the right lower lobe, peripherally located two adjacent round ground-glass opacities (arrows) and striking vascular enlargements (arrowheads) accompanied to lesions are demonstrated

CT: Computed tomography, COVID-19: Coronavirus disease-2019
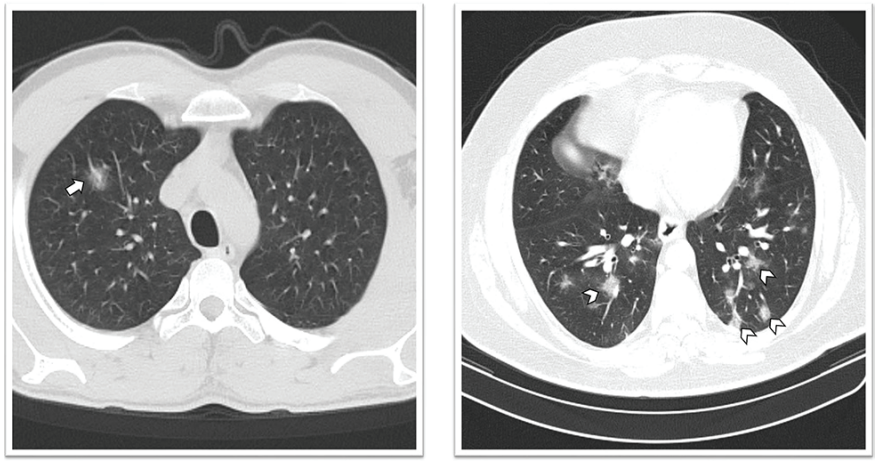

Figure 4: The CT findings of two different patients with COVID-19 positive in terms of the number of lesions are exhibited. On the left, interpretation of CT examination was reported as "Intedetermined type" as stated in the consensus, a solitary ground-glass opacity (arrow) with vascular enlargement located in peribronchovascular is shown. Peripheral and peribroncovascular located, multifocal, round, groundglass opacities (arrowheads) involving the bilateral lower lobes are shown on the right. CT interpretation of this patient was reported as "typical type" as stated in the consensus

CT: Computed tomography, COVID-19: Coronavirus disease-2019 in detection of asymptomatic individuals and patients with mild to moderate clinical findings is a vast challenge in coping with the outbreak. Late detection of asymptomatic individuals and patients with mild to moderate clinical findings causes the spread of infection rapidly, creating a significant public health problem.

In our study, 36 (36/214, 16.8\%) patients were asymptomatic and in close contact with a COVID-19 positive patient, and 178

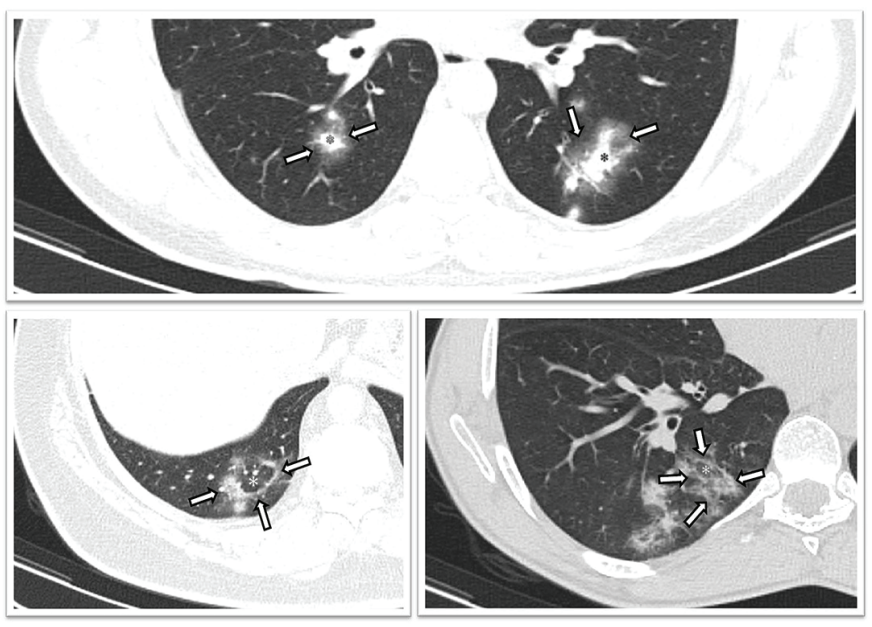

Figure 5: Axial CT image (above) reveals a ground-glass halo (arrows) surrounding a denser nodule or a consolidation (asterisk). Axial two CT image (below) of different patients reveals a reversed-halo formed by a dense ring (arrows) encircling a central area of GGO (asterisk)

CT: Computed tomography, GGO: Ground-glass opacity



Figure 6: The left (above) axial CT image shows thickened intralobular septa like a web (arrows) superimposed on a background of ground-glass opacity constituting "crazy paving" pattern. On the right axial $\mathrm{CT}$, the image shows another "crazy paving" pattern with an air bronchogram (arrow) in the right lung. The last axial CT image (below) demonstrates bilateral and subpleural linear lines (arrows)

CT: Computed tomography 
$(178 / 214,83.2 \%)$ patients had mild to moderate symptoms. While $129(129 / 161,80.1 \%)$ of 161 patients diagnosed with COVID-19 were symptomatic, $32(32 / 161,19.9 \%)$ were asymptomatic. The frequency of asymptomatic COVID-19 patients is higher than that reported by Mizumoto et al. (15) (17.9\%), while it is almost similar to that reported by Kim et al. (16) (19.2\%).

It was significant that the frequency of COVID-19 positivity in asymptomatic individuals was higher than that in presenting with any symptoms. The COVID-19 positivity rate $(32 / 36,88.9 \%)$ in asymptomatic individuals was higher than the screening performed on the Diamond Princess cruise ship (24/86, 27.9\%) (17). This high rate may be due to the already higher risk of having COVID-19 positivity in asymptomatic individuals, whose close contact with COVID-19 positive cases was detected by surveillance and referred to the hospital.

Currently, consecutive nasopharyngeal and oropharyngeal swab sampling, tested by RT-PCR, is accepted as the reference standard for definitive diagnosis of COVID-19 (18). It is known that it takes time to complete the RT-PCR test, and often because of insufficient material in the samples, false-negative results creates a disadvantage in the control of the outbreak $(19,20)$. Many factors are likely to affect the performance of the RT-PCR test. It can be influenced by several factors, such as viral load in the respiratory tract, operator-dependent sampling procedures that directly affect the test's performance, and the timing of sample taking. In a few studies, the initial chest CT examination's sensitivity (98\%) was remarkably higher than the initial PCR test (21). In our study, the sensitivity of the initial RT-PCR test was calculated to be $90.96 \%$. This value is higher than the previously reported ones. In the early period of the pandemic, the reported low sensitivity values maybe since the RT-PCR test kit has not yet matured in the early period and that adequate checks have not been carried out for justifiable reasons such as rapid deployment. In our study, 16 patients diagnosed with COVID-19 had negative initial RT-PCR test results. While 8 of 16 patients were consistent with COVID-19 on $\mathrm{CT}$, the other half did not have pneumonia. Thirteen patients who met the case definition were symptomatic, and 2 were with close contact. These patients were positive for PCR tests on the repeated second or $3^{\text {rd }}$ test, in the time interval mean of 2.1 days. CT scans were not needed again, as none of them had signs of severe disease or risk factors for disease progression. In this context, RT-PCR, which is the standard reference test for now, in case of false negativity, the contribution of chest CT scanning to patient management, especially in individuals without the severe disease, was not found to be useful in our study.

\section{Study Limitations}

However, as a limitation of our study, it may not be possible to investigate this generalization's validity with a small number of cases. It is a real need to conduct multicentric and multidisciplinary studies in the broader group of cases and to agree on the contribution of CT in screening according to disease severity and regions with low and high prevalence.

It is not surprising that in the early period of the pandemic, chest CT examination was preferred more in the diagnosis because of limited availability of RT-PCR tests in some countries and the lack of sufficient staff and medical equipment to perform the test. Moreover, the CT examination is cheaper and more accessible. Similar to the RT-PCR test, chest CT may be false-negative, especially in individuals with mild clinical signs or who are asymptomatic. Besides, there are many infectious agents and non-infectious pathologies that can cause similar findings in chest $\mathrm{CT}$, and these are indications that $\mathrm{CT}$ may not have as good specificity as the RT-PCR test. In our study, the sensitivity and specificity of chest CT in the diagnosis of COVID-19 were $41.61 \%$ and $84.9 \%$, respectively. Indeed, this sensitivity value is too low to fight the pandemic, especially in geographies, where the majority of patients are asymptomatic or mild. In the early period of the pandemic, the chest CT sensitivity in the literature was higher in the studies conducted in China, where the outbreak started. High rates of the chest CT sensitivity may be due to the high number of hospital admissions of the first pandemic cases, which usually present severe symptoms. As the outbreak progressed and screening tests increased, milder clinical manifestations and asymptomatic cases were relatively higher than those in severe cases. Studies showed that individuals who are COVID-19 positive and asymptomatic might not have pneumonia on CT (22).

In the study conducted by Ai et al. (23) it was stated that when RT-PCR test samples were obtained from the throat alone, the sensitivity of the RT-PCR test was found to be 59\% (601/1014). Mohammadi et al. (24) have investigated the accuracy of different respiratory tract samples for the COVID-19 RT-PCR test; they found that sputum samples were the most accurate ones in diagnostic sampling, followed by the nasal swab. They do not recommend using throat swabs alone for diagnostic sampling. Samples in our study combined nasalthroat swab for each patient were obtained. The RT-PCR test's high sensitivity in our study may result from using both nasal and throat swabs, obtaining samples with high viral load.

Studies suggest its use as a primary tool in the diagnosis of COVID-19, because of the high sensitivity of chest CT (23). Fleischner society, involving multidisciplinary and predominantly radiologists and pulmonologists, made some suggestions at the consensus meeting on April 1, 2020. According to this consensus, imaging should not be used as a screening test for COVID-19 in asymptomatic individuals. Imaging is not indicated for patients with a mild clinical manifestation of COVID-19 unless there is a risk factor for COVID-19 clinical progression (over 65 years of 
age and comorbid conditions). Regardless of patients' clinical severity with COVID-19, imaging is indicated if there is any evidence of worsening respiratory status during follow-up (10). These suggestions are essential to avoid CT procedures involving unnecessary ionizing radiation and reduce the contamination of radiology units/rooms by reducing viral loads. As low as reasonably achievable (ALARA) refers to the principles adopted to justify the radiological examinations and perform them at the lowest possible dose to protect patients from the possible harmful radiation exposure effects. The pandemic process is still ongoing, and CT examinations are being performed every day for more and more individuals who will perhaps never undergo tomography during their daily lives. The CT examinations are known to cause a potential increase in cancer risk in the long term (25). Unfortunately, it can be predicted that many cancer cases may be encountered in the post-pandemic period.

\section{Conclusion}

In conclusion, in patients infected with SARS-CoV-2 (COVID-19), and asymptomatic or mild to moderate symptomatic at admission, the sensitivity of the RT-PCR test is higher than that of chest CT. The use of chest CT in this subgroup of patients for diagnosis or screening at admission is controversial. Considering to avoid the stochastic effects of ionizing radiation, chest CT should be used cautiously in cases whose access to RT-PCR tests is not limited. Chest CT's advantages should always outweigh their risks. While CT is planned for any indication during the COVID-19 pandemic, possible long-term adverse effects should be well evaluated by both clinicians and radiologists, and it should be kept in mind that adherence to the ALARA principles is vital.

\section{Ethics}

Ethics Committee Approval: This study was performed in line with the principles of the Declaration of Helsinki. Clinical Research Ethics Committee of University of Health Sciences Turkey, Abdurrahman Yurtaslan Ankara Oncology Health Practice and Research Center granted approval for this retrospective data analysis (date: 24.06 .2020$, no: $2020-06 / 679$ ).

Informed Consent: Retrospective study.

Peer-reviewed: Externally peer-reviewed.

\section{Authorship Contributions}

Medical Practices: H.B., N.E., Concept: H.B., N.E., T.N.Ö., S.A.G., M.K., Design: H.B., N.E., Ö.A., C.D., Data Collection or Processing: H.B., N.E., M.K., C.D., A.S., Analysis or Interpretation: H.B., M.K., Ö.A., A.S., Literature Search: H.B., T.N.Ö., E.G.A., S.A.G., M.K., Writing: H.B.

Conflict of Interest: The authors declare that they have no conflict of interest.
Financial Disclosure: This study did not receive any specific grant from funding agencies in the public, commercial, or notfor-profit sectors.

\section{References}

1. Li B, Li X, Wang Y, et al. Diagnostic value and key features of computed tomography in Coronavirus Disease 2019. Emerg Microbes Infect. 2020;9:787-793.

2. Riou J, Althaus CL. Pattern of early human-to-human transmission of Wuhan 2019 novel coronavirus (2019-nCoV), December 2019 to January 2020. Euro Surveill. 2020;25:2000058.

3. Liu K, Fang YY, Deng Y, et al. Clinical characteristics of novel coronavirus cases in tertiary hospitals in Hubei Province. Chin Med J (Engl). 2020;133:10251031.

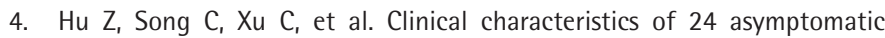
infections with COVID-19 screened among close contacts in Nanjing, China. Sci China Life Sci. 2020;63:706-711.

5. He JL, Luo L, Luo ZD, et al. Diagnostic performance between CT and initial real-time RT-PCR for clinically suspected 2019 coronavirus disease (COVID-19) patients outside Wuhan, China. Respir Med. 2020;168:105980.

6. Wang $W, X u Y, G a o$, et al. Detection of SARS-CoV-2 in Different Types of Clinical Specimens. JAMA. 2020;323:1843-1844.

7. Guan WJ, Ni ZY, Hu Y, et al. Clinical Characteristics of Coronavirus Disease 2019 in China. N Engl J Med. 2020;382:1708-1720.

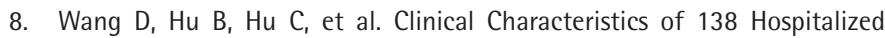
Patients With 2019 Novel Coronavirus-Infected Pneumonia in Wuhan, China. JAMA. 2020;323:1061-1069.

9. Xu B, Xing Y, Peng J, et al. Chest CT for detecting COVID-19: a systematic review and meta-analysis of diagnostic accuracy. Eur Radiol. 2020;30:57205727.

10. Rubin GD, Ryerson CJ, Haramati $L B$, et al. The Role of Chest Imaging in Patient Management During the COVID-19 Pandemic: A Multinational Consensus Statement From the Fleischner Society. Chest. 2020;158:106116.

11. Frush DP, Donnelly LF, Rosen NS. Computed tomography and radiation risks: what pediatric health care providers should know. Pediatrics. 2003;112:951957.

12. Şendur HN. Adherence to ALARA principle in the era of COVID-19 pandemic. Diagn Interv Radiol. 2021;27:153.

13. Clinical management of COVID-19: interim guidance, https://www.who.int/ publications/i/item/clinical-management-of-covid-19 (27 May 2020).

14. Simpson S, Kay FU, Abbara S, et al. Radiological Society of North America Expert Consensus Statement on Reporting Chest CT Findings Related to COVID-19. Endorsed by the Society of Thoracic Radiology, the American College of Radiology, and RSNA - Secondary Publication. J Thorac Imaging. 2020;35:219-227.

15. Mizumoto K, Kagaya K, Zarebski A, et al. Estimating the asymptomatic proportion of coronavirus disease 2019 (COVID-19) cases on board the Diamond Princess cruise ship, Yokohama, Japan, 2020. Euro Surveill. 2020;25:2000180.

16. Kim GU, Kim MJ, Ra SH, et al. Clinical characteristics of asymptomatic and symptomatic patients with mild COVID-19. Clin Microbiol Infect. 2020;26:948.e1-948.e3

17. Yamagishi T, Kamiya H, Kakimoto K, et al. Descriptive study of COVID-19 outbreak among passengers and crew on Diamond Princess cruise ship, Yokohama Port, Japan, 20 January to 9 February 2020. Euro Surveill. 2020;25:2000272.

18. Corman VM, Landt O, Kaiser M, et al. Detection of 2019 novel coronavirus (2019-nCoV) by real-time RT-PCR. Euro Surveill. 2020;25:2000045.

19. Hui DSC, Zumla A. Severe Acute Respiratory Syndrome: Historical, Epidemiologic, and Clinical Features. Infect Dis Clin North Am. 2019;33:869889. 
20. Peiris JS, Chu CM, Cheng VC, et al. Clinical progression and viral load in a community outbreak of coronavirus-associated SARS pneumonia: a prospective study. Lancet. 2003;361:1767-1772.

21. Fang $Y$, Zhang $H, X i e ~ J$, et al. Sensitivity of Chest CT for COVID-19: Comparison to RT-PCR. Radiology. 2020;296:E115-E117.

22. Li K, Fang Y, Li W, et al. CT image visual quantitative evaluation and clinical classification of coronavirus disease (COVID-19). Eur Radiol. 2020;30:44074416.
23. Ai T, Yang $Z$, Hou H, et al. Correlation of Chest CT and RT-PCR Testing for Coronavirus Disease 2019 (COVID-19) in China: A Report of 1014 Cases. Radiology. 2020;296:E32-E40.

24. Mohammadi A, Esmaeilzadeh E, Li Y, et al. SARS-CoV-2 detection in different respiratory sites: A systematic review and meta-analysis. EBioMedicine. 2020;59:102903.

25. Brenner DJ, Hall EJ. Computed tomography--an increasing source of radiation exposure. N Engl J Med. 2007;357:2277-2284. 